\title{
INFRASTRUCTURE, RESOURCES, SERVICES EVALUATION AND GAP ANALYSIS OF INTEGRATED MATERNAL AND CHILD DEVELOPMENT SERVICES IN INDIA
}

\author{
S. Kaur, R. Gupta, I. D. Khan, A. K. Jindal, \\ S. Prajapati, A. Makkar, K. S. Rajmohan \\ ARMY COLLEGE OF MEDICAL SCIENCES AND BASE HOSPITAL, NEW DELHI, INDIA
}

Background. Integrated Child Development Services (ICDS) is an Indian community-centric government program organized under Anganwadi centres catering to supplementary nutrition, health and preschool education, primary healthcare, growth monitoring and counselling the children under six years old along with their mothers. It is the world's largest outreach program in a developing country covering a population of 1.35 billion; the variations in service delivery were analysed involving cross-sectional rural and urban Anganwadi centers in New Delhi.

Methods. Data were collected by assessment of children and mothers, interview of Anganwadi workers and observation of service delivery parameters and conduction of activities. Infrastructural, beneficiaries, services and content were evaluated by a suitable pre-tested questionnaire based on the National Institute of Public Cooperation and Child Development (NIPCCD) evaluation proforma. The data was analysed by a descriptive statistics.

Results. Gaps were found in respect of infrastructure, resources, health and nutrition facilities especially at rural Anganwadi centre which was inadequate in terms of implementation of nutrition and health program, supplementary nutrition, preschool education and nutrition rehabilitation centre for existing beneficiaries. Both Anganwadi centres were not catering for new WHO growth standards and adolescent health.

Conclusions. Gaps found in respect of infrastructure, resources, health and nutrition facilities can affect performance of ICDS program and the services delivered by Anganwadi centres, which need a boost. Both urban and rural centres have a direct opportunity towards delivering adolescent health program focusing on nutrition and education of girls prior to their pregnancy, and adoption of new WHO growth standards.

KEY WORDS: ICDS, Anganwadi centre, nutrition, maternal health, growth charts.

\section{Introduction}

Integrated Child Development Services (ICDS) is a medico-social, gender-neutral, community-centric philanthropic program organized under rural courtyard shelters known as Anganwadi centres, catering to supplementary nutrition, nutrition and health education, preschool non-formal education, primary healthcare, immunization and growth monitoring of the children under six years old along with their mothers [1]. ICDS was launched in 1975 in accordance with the National Policy for Children in 33 places throughout India complemented by 13.3 lakh Anganwadi centres across the country. Organization of ICDS is implemented at five different levels, i.e. Central

Corresponding author: Dr Inam Danish Khan, MBBS, MD, DNB, DHCM, MIPHA, MISCD, Associate Professor (Clinical Microbiology and Infectious Diseases), Army College of Medical Sciences and Base Hospital, Delhi Cantt 110010 India E-mail: titan_afmc@yahoo.com,

Mobile: +91 8076324060, Fax: +911125693490
Level, State/Union Territory Level, District Level, Block Level and Village Level covering rural areas, tribal areas and urban slums to serve the extremely underprivileged communities of backward and remote areas of the country. Each Anganwadi centre covers 40-42 children from 0-6 years old and 20-25 pregnant and lactating mothers delivering services right at the doorsteps of the beneficiaries to ensure their maximum participation [2]. The ICDS team comprises Child Development Project Officers, District Program Officers, and auxiliary staff.

Being the world's largest outreach program in targeting infants and children below six years old, expectant and nursing mothers, the ICDS has generated interest worldwide among academicians, planners, policy makers, administrators and those responsible for its implementation [3]. Given its effectiveness over the last few decades, the Government of India is committed towards ensuring universal availa- 
bility of ICDS. The ICDS program at Anganwadi centres that are meant to adhere to certain laid-down standards given by the government for various infrastructural, resource and service parameters, for optimal functioning of the unit. The resources/infrastructure available on ground and services delivered vary widely. These variations account for the difference in standards of service-delivery, which in-turn might make a difference in overall effectiveness of ICDS. Thus, the availability of infrastructure, human resources and delivery of services should be studied and compared against the laid-down standards, for ascertaining gap analysis. It is obvious that bridging the gaps will help improve the program and offset malnutrition. Various evaluations of ICDS have revealed outcomes requiring improvement in the nutritional status of children which were falling short of expectations. This crosssectional study has evaluated and analysed the gap, with respect to infrastructure, resources and ICDS services vis $a$ vis the laid-down standards, at rural and urban Anganwadi centres in New Delhi.

\section{Methods}

A cross-sectional evaluation study was carried out among two Anganwadi centres in New Delhi. The data were collected by assessment of children and mothers, interview of Anganwadi workers and observation of service delivery parameters and conduction of activities. Infrastructural assessment of ICDS program via Anganwadi centres was done by observing building infrastructure, floor, roof, electricsupply, availability of kitchen or washroom, kitchen-utilities, drinking-water, preschool education material, guidebook, growth charts, proportion of malnourished children, supplementary nutrition to pregnant females, counselling activities towards nutrition, health, immunization, maintenance of records about beneficiaries and services availed. Suitable pretested and adequately modified questionnaire based on the National Institute of Public Cooperation and Child Development (NIPCCD) evaluation proforma was designed to interview the Anganwadi worker and the beneficiaries (mothers/children). Data was analysed under descriptive statistics.

\section{Results}

Both Anganwadi centres rented cemented building with adequate indoor space, childfriendly unisex toilets, electricity supply and water. Both Anganwadi centres were provided with hot cooked food containing a varied combination of pulses, cereals, oil, vegetables and sugar as well as take-home rations. The urban and rural Anganwadi centres involved 11 and 12 pregnant women, seven lactating women each, 35 and 36 children aged from 6 months to 3 years, as well as 30 and 18 children aged 3-6 years respectively. No children were found to be underweight. No adolescent girls were beneficiaries at either Anganwadi centres. Pregnant women were counselled towards utilisation of key services i.e. antenatal care, iron and folic-acid supplementation, adequate extra-care from family and rest during pregnancy. There was no interruption in supplementary nutrition in past six months. Supplementary nutrition program in urban Anganwadi centre was more effectively used by beneficiaries as compared to rural Anganwadi centre, where quality was neither satisfactory nor accepted by beneficiaries, while it was adequately accepted in the urban centre. In rural Anganwadi centre, Nutrition and Health Education program was not followed. As for infrastructural facilities, both Anganwqadi centres had good electricity supply with electric points above 5 feet from ground that was safe for children. Direct tapwater was stored in covered containers as per standards however there was no provision of either water-filters or reverse osmosis plants.

New WHO growth standards were not implemented in both Anganwadi centres, but weighing, plotting, interpretation and counselling of mothers were accurately performed and they were provided with WHO Growth chart. Early childhood care and education program was conducted in both Anganwadi centres every month as per laid-down standards. Urban Anganwadi centre was adequately provided with preschool education materials such as time-table, guide-book for story-telling, counting numbers, free conversation sessions to enable speaking and organized smallactivities related to fine muscle coordination and development such as painting, drawing, threading and matching colour, reading simple words, writing alphabets words, distinguish objects, recognise pictures etc. The rural Anganwadi centre was also provided with preschool education materials but not adequate ones as per laid-down standards.

Both Anganwadi centres were undertaking routine health check-up. It was noted that in the urban Anganwadi centre, the frequency of health check-up was monthly for children aged 
1-3 years, quarterly for children aged 3-6 years, and four check-ups were provided to pregnant females starting in first trimester. In rural Anganwadi centre, pregnant females were seen only twice starting in second-trimester. Both Anganwadi centres didn't include adolescent girls for health check-up. In both Anganwadi centres, immunization program was running effectively. Iron and Vitamin A supplementation were provided to children and pregnant women under the ICDS program.

\section{Discussion}

Recognizing the need for early intervention to ensure the development of a young child's body, mind, and intellect to its maximum potential, the Government of India started the ICDS, a centrally sponsored scheme, which is a step toward responding to the child's needs in a comprehensive and holistic perspective. The national goals of ICDS program are reduction of infant mortality rate to $<60 / 1000$, reduction in child mortality rate to $<10 / 1000$, and reduction in maternal mortality rate by at least $50 \%$, through a focused health check-up, immunization, deworming, basic treatment of minor illnesses like fever, diarrhoea etc., referral services for severe illness, supplementary feeding, growth monitoring and early childhood day care $[4,5]$.

Infrastructural evaluation was satisfactory in this study whereas other studies found toilet facilities present only in $57.1 \%$ Anganwadi centres $[6,7]$. The rural Anganwadi centre was lagging the laid-down standards towards nutrition and health program, supplementary nutrition, preschool education and adoption of nutrition rehabilitation centre, which was also found in other rural Anganwadi centres in India by various studies $[8,9,10,11]$. These services are meant for effective transmission of certain basic health and nutrition messages to enhance the level of awareness of mothers about the child's needs and their capacity for care, protection, and development of the child. Supplementary nutrition is strategic as it not only improves the nutritional level of children and reduces malnutrition, but it also works as an incentive for promoting attendance of children and mothers to participate in the activities of Anganwadi centres, and as such plays a vital role in ICDS program. Inadequacy on these fronts bears a direct connotation towards inadequate service delivery and fetomaternal outcomes as India is mostly a rural country and requires strengthening of rural Anganwadi centres $[12,13,14,15]$.

In current study it was also observed that the new WHO growth standards were not implemented in both Anganwadi centres, but weighing, plotting, interpretation and counselling of mothers were accurately performed, and they were provided with the WHO Growth chart. Similarly, adolescent health is a completely neglected area under the ICDS program which needs to be intensified to ensure nutrition and health of girls prior to pregnancy to enable them to make better choices towards family planning, contraception and perinatal care of themselves and their children [16]. In turn, this will universalize and maximise the concept development of ICDS program in context and content; and further capacity building initiatives amongst beneficiaries for better families, better management of Anganwadi centres and a sustainably better future in a tropical developing country withholding a population of 1.35 billion $[17,18,19]$.

\section{Conclusions}

Gaps found in respect of infrastructure, resources, health and nutrition facilities can directly affect the performance of ICDS program and the services delivered by the Anganwadi centres. There is a felt opportunity to boost the service delivery ecosystem of rural Anganwadi centre in term of implementation of nutrition and health program, supplementary nutrition, preschool education and nutrition rehabilitation centre for existing beneficiaries. Both urban and rural centres have a direct opportunity towards delivering adolescent health program focusing on nutrition and education of girls prior to their pregnancy, in order to maximise the potential of ICDS program and universalise the acceptance and availability of ICDS. There is a scope of improving upon adoption of new WHO growth standards. 


\title{
ІНТЕГРОВАНІ ЦЕНТРИ МАТЕРІ І ДИТИНИ В ІНДІї: ІНФРАСТРУКТУРА, РЕСУРСИ, ОЦІНКА ДІЯЛЬНОСТІ ТА ПРОГАЛИНИ У РОБОТІ
}

\author{
S. Kaur, R. Gupta, I. D. Khan, A. K. Jindal, \\ S. Prajapati, A. Makkar, K. S. Rajmohan \\ ARMY COLLEGE OF MEDICAL SCIENCES AND BASE HOSPITAL, NEW DELHI, INDIA
}

Вступ. Об'єднані центри дитячого розвитку (ICDS) - це державна соціально-орієнтована програма у Індії під егідою Анганваді чентрів, яка забезпечує додаткове харчування, санітарно-гігієнічну просвітницьку діяльність та дошкільну освіту, надання первинної медичної допомоги, моніторинг та консультування дітей віком до шести років разом з їхніми матерями. Це найбільша у світі за охопленням (коло 1,35 мільйонів населення) програма у країнах, які розвиваються.

Мета роботи - проаналізувати діяльність Анганваді центрів у міській та сільській місцевостях Нью Делі.

Методи. Дані збиралися шляхом опитування матерів та дітей і працівників Анганваді центрів, а також оцінки діяльності центрів. Опитувальники щодо інфраструктури, переваг та наданих центрами послуг базувалися на формі, запропонованій Національним інститутом громадського співробітництва та розвитку дітей. Дані аналізувалися за допомогою описової статистики.

Результати. Були знайдені недосконалі моменти у роботі Анганваді центрів, особливо у сільській місцевості, а саме щодо термінів впровадження програм здорового харчування та дошкільної освіти та програм реабілітації. У обох центрах не було запроваджено нові стандарти ВоОз.

Висновки. Виявлені прогалини можуть вплинути на ефективність роботи об'єднаних центрів дитячого розвитку та якість послуг, які надаються у Анганваді центрах. Однак, як міські, так і сільські центри мають можливість здійснювати програми охорони здоров'я підлітків, зосереджуючись на харчуванні та вихованні дівчат до їх вагітності, а також прийняття нових стандартів ВООз.

КЛЮЧОВІ СЛОВА: ICDS програма; Анганваді центр; харчування; репродуктивне здоров'я жінок; розвиток дітей.

\section{References}

1. Integrated Child Development Services (ICDS) Scheme, Child Development. New Delhi: Ministry of Women and Child Development, Government of India. Rapid Facility Survey of Infrastructure at AnganwadiCenters (RFS-AWCs) by NCAER. Available from: http://wcd.nic.in/icds.htm.

2. Kapil U, Sachdev HP. Recommendations: national consultation to review the existing guidelines in ICDS scheme in the field of health and nutrition. Indian Pediatr. 2002;38:721-31.

3. Patil SB, Doibale MK. Study of profile, knowledge and problems of Anganwadi workers in ICDS blocks: A cross sectional study. Online J Health Allied Sci 2013;12:1. http://www.ojhas.org/ issue46/2013-2-1.html.

4. Three Decades of ICDS - An Appraisal. National Institute of Public Cooperation and Child Development (NIPCCD), 2006.http://www.nipccd.nic.in/reports/ icdsvol3.pdf.

5. Thakare MM, Kurll BM, Doibale MK, Goel NK. Knowledge of anganwadi workers and their problems in an urban ICDS block. J Med Coll Chandigarh. 2011;1(1):15-9.

6. Chudasama RK, Patel UV, Verma PB, Vala M, Rangoonwala $M$, Sheth A, Viramgami A. Evaluation of anganwadi centres performance under Integrated
Child Development Services (ICDS) program in Gujarat state, India during year 2012-13. Journal of Mahatma Gandhi Institute of Medical Sciences. 2015 Jan 1;20(1):60.

7. Datta SS, Boratne AV, Cherian J, Joice YS, Vignesh JT, Singh Z. Performance of Anganwadi centres in urban and rural area: A facility survey in Coastal South India. Indian J Matern Child Health 2010;12:1-9.

8. ICDS IV project (IDA assisted). New Delhi: Ministry of Women and Child Development, Government of India. Guidelines and Processes to be followed for the preparation of State Project Implementation Plans and District Annual plans, Central Project management Unit. February 2008.

9. Dhingra R, Shrama I. Assessment of preschool education component of ICDS scheme in Jammu district. Global J Human Social Sci. 2011;11(6):13-8.

10. Kapil U, Saxena N, Nayar D, Gnanasekaran N. Status of growth monitoring activities in selected ICDS projects in Rajasthan. Indian Pediatr 1996; 33:949-52.

11. Gurukartick J, Ghorpade AG, Thamizharasi A, Dongre AR. Status of Growth Monitoring in Anganwadi Centres of a Primary Health Centre, Thirubhuvanai, Puducherry. Online J Health Allied Scs. 2013; 
12(2):2. Available from: http://www.ojhas.org/ issue46/2013-2-2.html

12. Sood AK, Sood VP. The evaluation of supplementary nutrition component of ICDS - a study at block Beri, Rohtak, Haryana. Health \& Population Perspectives and Issues. 1987;10:207-212.

13. Sharma M, Soni GP, Sharma N. Assessment of Coverage of Services among Beneficiaries Residing in Area Covered by Selected Anganwadi in Urban Project I and II of Raipur City. J Community Med Health Educ. 2013;3:195.

14. Saiyed F, Seshadri S. Impact of the integrated package of nutrition and health services. Indian J Pediatr. 2000;67:322-8.

15. Khan S, Bal H, Khan ID, Paul D. Feto-Maternal Outcome In Women Diagnosed For Gestational Diabetes Mellitus in Western India: A two-year prospective study. Iranian Journal of Diabetes and
Obesity.Epub Ahead of print.2018, eISSN 2345-2250, ISSN 2008-6792.

16. Khan ID. KAPB study on contraceptives among married armed forces personnel. Indian Journal for the Practicing Doctor. 2008;5:2.

17. Surwade JB, Mantri SB, Wadagale AV. Utilization of ICDS scheme in urban and rural area of Latur district with special reference to pediatric beneficiaries. International J Recent Trends Sci Technology. 2013;5:107-10.

18. Avachat S, Phalke VD, Phalke DB. Epidemiological study of malnutrition (under nutrition) among under five children in a section of rural area. Pravara Med Rev. 2009;1:20-2.

19. Dixit S, Sakalle S, Patel GS, Taneja G, Chourasiya S. Evaluation of functioning of ICDS project areas under Indore and Ujjain divisions of the state of Madhya Pradesh. Online J Health Allied Scs. 2010;9(1):2. 